\title{
24. Re-Sr AND K-Ar AGE DETERMINATIONS ON SAMPLES OF THE FALKLAND PLATEAU BASEMENT AT SITE 330, DSDP
}

\author{
R.D. Beckinsale, ${ }^{1}$ J. Tarney, ${ }^{2}$ D.P.F. Darbyshire, ${ }^{1}$ and M.J. Humm ${ }^{3}$
}

\begin{abstract}
A rubidium-strontium whole-rock isochron obtained on samples of pelitic to semipelitic metasedimentary gneiss recovered from the basement of the Falkland Plateau at Site 330 corresponds to an age of $535 \pm 66 \mathrm{~m} . \mathrm{y} .\left(\lambda \beta=1.47 \times 10^{-11} \mathrm{a}^{-1}\right)$ with an initial ${ }^{87} \mathrm{Sr} /{ }^{86} \mathrm{Sr}$ ratio of $0.7309 \pm 0.0045$. The age probably relates to metamorphic or hydrothermal events recorded in the basement rocks: this fits in well with the regional geochronology of the reconstructed Gondwanaland continent. However the data allow the possibility of a considerably older age for the sediments themselves. The granite pegmatite intruding the gneisses is more radiogenic than the gneisses, but the $\mathrm{Rb} / \mathrm{Sr}$ data do not define an isochron.

$\mathrm{K}-\mathrm{Ar}$ ages of $399 \pm 10 \mathrm{~m} . \mathrm{y}$. and $287 \pm 7 \mathrm{~m} . \mathrm{y}$. for samples of gneiss and pegmatite, respectively, appear to represent ${ }^{40} \mathrm{Ar}$ loss related to contact metamorphism by adjacent intrusions.
\end{abstract}

\section{INTRODUCTION}

The metamorphic and igneous basement rocks penetrated beneath Jurassic sediments in Cores 16 and 17 at Site 330 demonstrate conclusively that the easternmost segment of the Falkland Plateau, South Atlantic, is underlain by continental material. Granitic and gneissic rocks of similar type crop out in the vicinity of Cape Meredith in the Falkland Islands (Islas Malvinas) (Baker, 1924; Greenway, 1972) where they are overlain unconformably by rocks of presumed lower Devonian age. However, no published radiometric ages are available from the Cape Meredith Complex.

The Falkland Plateau and adjoining areas of the sea floor bounded by the 3000-meter isobath are continuous with the South American continent. This phase of the Deep Sea Drilling Project has established that it is necessary to incorporate the low-lying eastern extremity of the Falkland Plateau into any precontinental drift reconstructions of Gondwanaland. The main objective of the present study was to establish the age of the basement rocks and hence to identify any possible relationship with the known areas of pre-Jurassic basement in South America, South Africa, and Antarctica.

The petrology and geochemistry of the Hole 330 basement rocks is described by Tarney elsewhere in this volume. Briefly the main rock types represented consist of (a) a series of foliated semipelitic to pelitic gneisses of probable sedimentary origin; (b) thin concordant granitic veins $\left(\pi_{1}\right)$ which have suffered deformation and

\footnotetext{
'Institute of Geological Sciences, London, United Kingdom.

${ }^{2}$ Department of Geological Sciences, University of Birmingham, United Kingdom.

${ }^{3}$ Department of Geology and Mineralogy, University of Oxford, United Kingdom.
}

recrystallization; (c) a thick granite pegmatite $\left(\pi_{2}\right)$ in Core 17, with equivalent thinner pegmatitic veins elsewhere in the core and which have not undergone substantial recrystallization; (d) later thin basic veins which cut the gneisses; and (e) a fine-grained microsyenite which cuts the granitic pegmatite in the lowermost part of Core $17(17, \mathrm{CC})$, which may or may not be part of a larger intrusion.

Hopes of a successful outcome to the dating program were not held to be very high after preliminary examination of the core. In the first place, a variety of rock types are represented in this relatively short section of core, and their relationships can only be inferred: normally in a continental exposure one would have three-dimensional control and a choice of suitable samples. In the second place there has been extensive hydrothermal recrystallization of the biotites (one of the main ${ }^{40} \mathrm{~K},{ }^{87} \mathrm{Rb}$, and ${ }^{87} \mathrm{Sr}$ bearing phases) throughout the core. Thirdly, the presence of substantial basement calcrete near the top of Core 16, together with thin calcite veins and replacement of plagioclase by carbonate throughout the upper part of the core, indicate an extended period of ground-water activity prior to burial. To minimize the effects of the latter, samples for the dating program were taken only from Core 17. Finally, an unknown factor is the size and extent of the later basic and microsyenite intrusions and their possible thermal effects on the parent and daughter radioisotopes in the gneisses and pegmatites.

\section{SAMPLE PREPARATION, ANALYTICAL METHODS, AND RESULTS}

Samples were extracted from the core by slicing longitudinally with a diamond saw into quarters and allowing as great a length as possible consistent with homogeneity. Each sample was washed thoroughly with demineralized water to remove as much seawater 
contaminant as possible. Inevitably the sample size is much smaller than that normally used in the dating of such rocks. Each longitudinal section of core was crushed either to -40 to +80 mesh powder for argon analysis, or to a very fine powder for rubidium and strontium analysis. An aliquot of each -40 to +80 mesh powder was reduced further to a fine powder for potassium analysis. Potassium-argon ages have been determined on one sample of granite pegmatite and one of gneiss. $\mathrm{Rb}-\mathrm{Sr}$ and ${ }^{87} \mathrm{Sr} /{ }^{86} \mathrm{Sr}$ ratios have been determined on three whole-rock samples of the granite pegmatite and four whole-rock samples of gneiss. The range of $\mathrm{Rb}-\mathrm{Sr}$ ratios in both the analyzed gneisses and the granite pegmatite is rather restricted (Tarney, this volume).

The analytical methods and error calculations used in potassium-argon age determinations have been described by Beckinsale and Obradovich (1973). The ages have been calculated using the decay constants for ${ }^{40} \mathrm{~K}$ and other parameters recommended by Beckinsale and Gale (1969), and the results are given in Table 1.

Analytical methods used for rubidium-strontium age determination have been described by Beckinsale (1974), the only difference being that instead of AGX (Pankhurst and O'Nions, 1973) the X-ray fluorescence standard used was the USGS standard granodiorite GSP-1. The rubidium and strontium values adopted for GSP-1 were those of Pankhurst and O'Nions (1973). The results are summarized in Table 1, and the ${ }^{87} \mathrm{Sr} /{ }^{86} \mathrm{Sr}$ ratios are quoted relative to an Eimer and Amend value of 0.7080 . An isochron plot for the gneiss data is shown in Figure 1, but the pegmatite data do not define an isochron.

\section{INTERPRETATION OF RESULTS}

\section{Gneisses}

The four gneiss samples define an approximately linear array on the $\mathrm{Rb}-\mathrm{Sr}$ isochron diagram. The bestfit line computed to run through these points by the least-squares method of Williamson (1968) gives a slope corresponding to an age of $535 \mathrm{~m} . \mathrm{y}$. using a value of $1.47 \times 10^{-11} \mathrm{a}^{-1}$ for the decay constant of ${ }^{87} \mathrm{Rb}$. The scatter of points about the best-fit line is, however, out-

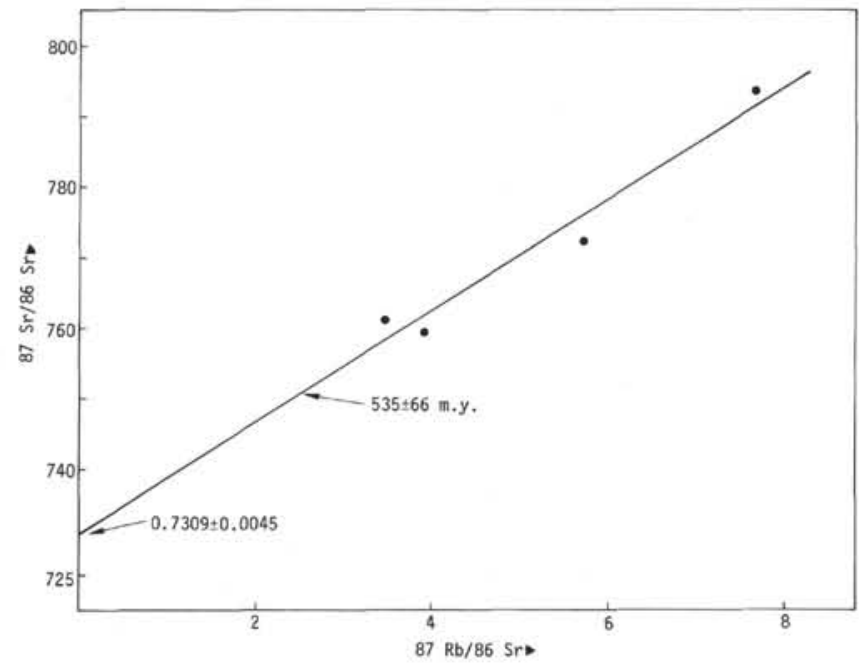

Figure 1. Rubidium-strontium isochron diagram for metasedimentary gneiss samples, Core 17, Site 330.

side that of experimental and instrumental errors and must include some "geological" factor. Therefore to compute more realistic errors in the age and initial ${ }^{87} \mathrm{Sr} /{ }^{86} \mathrm{Sr}$ ratio, the experimental errors were multiplied by a factor of 3.1 in order to bring the ratio of the squared residuals to the degrees of freedom down to 2.5. On this basis the whole-rock "isochron" for the gneisses gives an age of $535 \pm 66 \mathrm{~m}$.y. with an initial ${ }^{87} \mathrm{Sr} /{ }^{86} \mathrm{Sr}$ ratio of $0.7309 \pm 0.0045$ m.y. The errors are quoted at the one sigma level, and include geological as well as analytical uncertainty. A possible contributory factor in the geological uncertainty might be the relatively small size of the available whole-rock samples, which were of the order of a few hundred grams in contrast to the 5 to $25 \mathrm{~kg}$ normally preferred for $\mathrm{Rb}-\mathrm{Sr}$ analysis. The geological significance of the $\mathrm{Rb}$ - $\mathrm{Sr}$ whole-rock isochron age of $535 \pm 66 \mathrm{~m}$.y. is not immediately self-evident, and there are several possible interpretations. The age could reflect:

1) Homogenization of the strontium-isotope ratios during diagenesis following deposition of the original pelitic to semipelitic sediments, with differences in the

TABLE 1

Rubidium-Strontium and Potassium Argon Data for Samples of Metasedimentary

Gneiss and Granite Pegmatite, Core 17, Site 330

\begin{tabular}{|c|c|c|c|c|c|c|c|c|c|}
\hline Sample & Lithology ${ }^{a}$ & $\mathrm{Rb} / \mathrm{Sr}^{\mathrm{b}}$ & ${ }^{87} \mathrm{Sr} /{ }^{86} \mathrm{Sr}^{\mathrm{c}}$ & $\begin{array}{c}\mathrm{Rb}^{\mathrm{d}} \\
(\mathrm{ppm})\end{array}$ & $\begin{array}{c}\mathrm{Sr}^{\mathrm{d}} \\
(\mathrm{ppm})\end{array}$ & $\begin{array}{l}\mathrm{K}^{\mathrm{e}} \\
(\%)\end{array}$ & $\begin{array}{c}{ }^{40} \mathrm{Ar} \mathrm{rad} \mathrm{g} \mathrm{g}^{-1} \\
(\mathrm{scc})\end{array}$ & $\begin{array}{c}40 \mathrm{Ar} \text { atmos } \\
(\%)\end{array}$ & $\begin{array}{c}\text { K-Ar Age } \\
\text { and Error } \\
\text { (m.y.) }\end{array}$ \\
\hline $17-2,4$ & G & 2.628 & 0.7939 & 164 & 62 & - & - & - & - \\
\hline $17-2,8 \mathrm{~A}$ & G & 1.962 & 0.7723 & 162 & 83 & 2.553 & $4.436 \times 10^{-5}$ & 4.58 & $399 \pm 10$ \\
\hline $17-2,9$ & $\mathrm{G}$ & 1.190 & 0.7613 & 96 & 81 & - & - & - & - \\
\hline $17-2,18$ & G & 1.338 & 0.7594 & 150 & 112 & - & - & - & - \\
\hline $17-2,17$ & $\mathrm{P}$ & 2.656 & 0.8106 & 245 & 92 & - & - & - & - \\
\hline $17-2,15$ & $\mathrm{P}$ & 2.579 & 0.8149 & 247 & 96 & - & - & - & - \\
\hline $17-2,16 \mathrm{~A}$ & $\mathrm{P}$ & 2.900 & 0.8249 & 303 & 105 & 9.059 & $1.097 \times 10^{-4}$ & 3.26 & $287 \pm 7$ \\
\hline
\end{tabular}

${ }^{\mathrm{a}} \mathrm{G}=$ gneiss, $\mathrm{P}=$ granite pegmatite.

${ }^{\mathrm{b}}$ XRFS analyses, errors $\pm 1 \%$ ( 1 sigma).

${ }^{c}$ Normalized ${ }^{87} \mathrm{Sr} /{ }^{86} \mathrm{Sr}$ ratios, errors \pm 0.0003 (1 sigma).

${ }^{\mathrm{d}}$ XRFS analyses. Mass absorbtion coefficient estimated from Compton peak, errors $\pm 10 \%$ ( 2 sigma).

esee text for details of K-Ar analyses. 
$\mathrm{Rb} / \mathrm{Sr}$ ratio still being maintained. The high initial ${ }^{87} \mathrm{Sr} /{ }^{86} \mathrm{Sr}$ ratios would indicate derivation of the sediments from a relatively mature continental source with an insignificant volcanogenic component from younger mantle-derived igneous rocks. This points to the antiquity of continental material in this area.

2) Homogenization of strontium-isotope ratios during the regional metamorphic event or events which culminated in the crystallization of the strongly colored red biotite. Although the efficacy of metamorphism in resetting whole-rock (as opposed to mineral) isochrons has recently been questioned (Moorbath, 1975), the arguments put forward do not necessarily apply to the present rocks.

3) Homogenization of strontium isotopes during a contact metamorphic event associated with emplacement of the granite pegmatite or microsyenite, or the hydrothermal event linked with the extensive replacement of the red biotite by green and colorless micas and chlorite. In one case in the Antarctic (Faure et al., $1968 \mathrm{~b}$ ), it has been demonstrated that an $\mathrm{Rb}-\mathrm{Sr}$ wholerock isochron age ( $\left.432 \pm 16 \mathrm{~m} . \mathrm{y} ., \lambda \beta=1.47 \times 10^{-11} \mathrm{a}^{-1}\right)$ obtained for samples of metasediments of the LaGorce Formation in the central Transantarctic Mountains is essentially identical to the $\mathrm{Rb}-\mathrm{Sr}$ whole-rock isochron age of intrusion of local quartz monzonites $(450 \pm 10$ m.y.). The LaGorce Formation is intruded by granitic rocks of the Wisconsin Range batholith which have given an $\mathrm{Rb}-\mathrm{Sr}$ whole-rock isochron age of $589 \pm 22$ m.y. The LaGorce Formation is also apparently overlain by metavolcanics of the Wyatt Formation which have yielded an $\mathrm{Rb}-\mathrm{Sr}$ whole-rock isochron age of $595 \pm 13 \mathrm{~m} . \mathrm{y}$. The isochron age obtained for the LaGorce Formation is therefore far too young to reflect strontium isotope homogenization during either diagenesis or regional metamorphism, both of which must have occurred about 150 m.y. earlier.

Assessing the relative merits of linking the apparent isochron age to either of these events is difficult. An additional complicating factor is the possible leaching effect of the ground-water activity which produced the basement calcrete. The geochemical data (Tarney, this volume) indicate significant segregation of secondary copper in the calcrete at the top of the core with an equally significant leached zone below. However, most of Core 17 shows normal copper values, and we are inclined to think that the leaching action of ground-water has had minimal effect at the deeper level of the core from which the dating samples were taken. In any case there is no evidence that elements other than copper have been appreciably affected.

A more serious problem affecting interpretation is the nature and extent of the geochemical changes accompanying the hydrothermal activity. The microprobe data (Tarney, this volume) indicate appreciable loss of potash as the red biotites transform to green and colorless micas and chlorites. Since biotite is also a major rubidium-bearing phase in the gneisses, loss of rubidium and accumulated radiogenic strontium would also be expected. The whole-rock $\mathrm{K} / \mathrm{Rb}$ ratios are rather higher than is normal for micaceous gneisses (Tarney, this volume) suggesting that more rubidium than potassium has been lost from the rocks during the hydrothermal activity. On the other hand, it is likely that the loss of radiogenic strontium would have been greater than the loss of rubidium since while some rubidium would have been taken into the structures of the replacing green biotites, there is no comparable phase to take the radiogenic strontium other than plagioclase (which is present only in small amounts and in any case tends to be rather altered), or potassic feldspar (which shows no evidence of recrystallization at this stage).

These geochemical changes must be reflected to some extent in the observed isochron and must at least have contributed to the apparent scatter about the best-fit line and probably to an overall reduction in the slope of the isochron too. We suspect therefore that the 535m.y. slope of the isochron correlates either with the hydrothermal event or with the previous episode of metamorphic recrystallization and gneissification or some combination of the two. In either case, the observed high initial strontium ratios allow for the possibility that the ultimate age of the sediments could be very much older, certainly Precambrian.

The K-Ar age for the gneiss whole-rock Sample 330$17-2,8 \mathrm{~A}$ (Table 1) gives an age of $399 \pm 10$ m.y. (one sigma error). The potassium-bearing minerals in this rock are K-feldspar and green biotite/chlorite, both of which are known to lose radiogenic ${ }^{40} \mathrm{Ar}$ relatively easily (Dalrymple and Lanphere, 1969). The discordance between the K-Ar age of $399 \pm 10$ m.y. and the Rb-Sr whole-rock isochron age of $535 \pm 66 \mathrm{~m} . \mathrm{y}$. can be attributed to argon loss. The argon loss could have occurred during a specific thermal event such as the emplacement of the pegmatite, the hydrothermal alteration, or the intrusion of the microsyenite, or it could have occurred almost continuously.

\section{Granite Pegmatite}

The $\mathrm{Rb}-\mathrm{Sr}$ data for the granite pegmatite do not define even a crude linear array in an isochron diagram, and it is not possible to derive an age from these results. All the data points plot above the gneiss isochron, and if the granite pegmatite is $535 \mathrm{~m} . \mathrm{y}$. or younger, it must have had quite a high initial ${ }^{87} \mathrm{Sr} /{ }^{86} \mathrm{Sr}$ ratio. For instance, a line through the centroid of the $\mathrm{Rb}-\mathrm{Sr}$ data for the granite pegmatite with a slope equivalent to $535 \mathrm{~m} . \mathrm{y} .\left(\lambda \beta=1.47 \times 10^{-11} \mathrm{a}^{-1}\right)$ gives an initial ${ }^{87} \mathrm{Sr} /{ }^{86} \mathrm{Sr}$ of about 0.754 . An initial ratio of this magnitude precludes a low $\mathrm{Rb} / \mathrm{Sr}$ lower crustal or mantle source for the granite pegmatite, but would allow derivation by partial melting of rocks similar in geochemistry to the metasedimentary gneisses at depth, or necessitate contamination of any mantle-derived magma with appreciable crustal strontium.

The $\mathrm{K}-\mathrm{Ar}$ age for Sample 330-17-3, 16A is about 290 m.y. (Table 1). This sample represents a facies of the pegmatite rich in $\mathrm{K}$-feldspar. Although the K-feldspar in the pegmatite has some optical characteristics suggestive of sanidine, there is nevertheless incipient development of cross-hatched twinning indicative of partial transformation to microcline. Had the feldspar been sanidine (albeit in an unusual geological situation) 
the 290-m.y. age might have been valid since sanidine is known to retain radiogenic ${ }^{40} \mathrm{Ar}$ well (Dalrymple and Lanphere, 1969). However, a more likely explanation would be that the K-Ar age reflects argon loss, either continuously, or in some thermal event postdating the emplacement of the pegmatite. Such an event might well have been the emplacement of the microsyenite. It may be significant that the $\mathrm{K}-\mathrm{Ar}$ age of the pegmatite sample is lower than the $\mathrm{K}-\mathrm{Ar}$ age of the gneiss sample. The position of these two samples in the core relative to the microsyenite would indicate that the pegmatite sample was much closer to the microsyenite contact and hence may have suffered a greater thermal effect with consequently more complete loss of accumulated radiogenic argon.

In summary, the relatively complex geological history recorded in the basement rocks at Site 330 does not allow a unique and unambiguous interpretation of the $\mathrm{Rb}-\mathrm{Sr}$ and $\mathrm{K}-\mathrm{Ar}$ age data. A succession of thermal and geochemical events is available with which to correlate the apparent ages. Had Site 330 bottomed in a simpler geological situation, a less-flexible interpretation might well have been possible. Subjectively we feel that the metasedimentary gneisses, and possibly the pegmatite, also could be much older than the 535-m.y. isochron age suggests. The high initial ${ }^{87} \mathrm{Sr} /{ }^{86} \mathrm{Sr}$ ratios of the gneisses would certainly allow an earlier geological history well back into the Precambrian. Clearly on this basis the Falkland Plateau cannot be neglected in reconstructions of Gondwanaland. Nevertheless, the reality of important geological events between $\sim 535$ and $\sim 290$ m.y. in the area must also be faced, and comparisons with the major continental segments of Gondwanaland are made below.

\section{IMPLICATIONS FOR THE REGIONAL GEOCHRONOLOGY OF GONDWANALAND}

In the context of Gondwanaland, the geological history of southernmost Africa is that which is most readily compared with the Falkland Plateau. Metamorphic and igneous rocks of the craton are not exposed along the southernmost margin in South Africa although they underlie the Karroo System (Stratten, 1971) and are exposed around Durban (Haughton, 1969). In the southwestern Cape Province, the Malmesbury System and Cape Granites represent the oldest exposed orogenic belt (Haughton, 1969). The Malmesbury Formation, which consists largely of a graywacke shale sequence, is folded about axes trending northwest and is intruded by plutons of the Cape Granites. Radiometric dating indicates emplacement of the plutons at about 550 m.y. (Allsopp and Kolbe, 1965). Strata assigned the same late Precambrian age as the Malmesbury also crop out in the Cape Fold Belt.

The Cape Fold Belt, of late Paleozoic to early Mesozoic age, is the dominant orogenic belt in southernmost Africa, and in it the Cape System and lowermost Karroo System are deformed. An earlier phase of pre-Dwyka (?) mid-carboniferous deformation is recorded in the western Cape Province, but the principal event during which the major structures of the Cape Fold Belt were developed is believed to have at- tained a deformational peak in mid-Triassic time (Bishop and van Eeden, 1971). The structures strike east-west to east-southeast-west-northwest and are abruptly truncated at the continental margin. On the proposed reconstruction these structures strike into the eastern part of the Falkland Plateau. Although the Cape Fold Belt does not have any associated plutonic rocks, the Karroo Supergroup contains abundant volcanogenic material including airfall tuffs (Elliot and Watts, 1974; Fuller, 1971; Martini, 1974). The volcanogenic constituents are known to occur in the sequence from the lower Permian upper Dwyka Shales up into, probably, the upper Triassic Red Beds, and this clearly indicates that there was considerable igneous activity associated with the Cape Orogeny.

The rubidium-strontium whole-rock isochron data of $535 \pm 66$ m.y. fits well with the geochronological evidence in the Malmesbury System and Cape Granites for an early Paleozoic orogeny. The Falkland Plateau metamorphic rocks could well have undergone isotopic homogenization during that event. The younger potassium-argon dates may represent continued argon leakage from rocks of that age or, equally well, thermal events or igneous activity associated with the younger Cape Orogeny.

In the broader context of Gondwanaland early Paleozoic dates of about $500 \pm 50$ m.y. have been recorded from the Pampean Ranges of northwestern Argentina and the Sierra de la Ventana of eastern Argentina (Halpern, 1972). Late Paleozoic and early Mesozoic igneous activity has been demonstrated for the Patagonian Massif and Deseado Massif in southern Argentina (Halpern, 1968, 1971; Halpern et al., 1971, 1972; Stipanicic et al., 1971).

The geochronology of Antarctica has been summarized by Craddock (1972) and Krylov (1972). Antarctica shows evidence of both a late Precambrian event, the Beardmore Orogeny, and an early Paleozoic event, the Ross Orogeny (see Elliot, 1975; Faure et al., 1968a; Gunner and Faure, 1972; Grindley and McDougall, 1969; Pasteels and Michot, 1970). These orogenic belts can be recognized in the Transantarctic Mountains from near the head of the Weddell Sea across the continent. The errors in the isochron do not allow distinction between the two orogenies. Early Mesozoic deformation is recorded in the Pensacola and Ellsworth mountains, as well as in the Antarctic Peninsula, and constitutes the Antarctic evidence of the Gondwanian Orogeny.

It is clear that the isochron yielded by the Site 330 metamorphic rocks fits well with the regional geochronology of this part of Gondwanaland, in particular with the Cape Granites and Malmesbury deformation. The younger potassium-argon ages of the gneisses and pegmatite are consistent with resetting of older dates by thermal events or igneous activity during the Cape Orogeny.

\section{ACKNOWLEDGMENTS}

We are indebted to R.K. O'Nions and R.J. Pankhurst for their help with the strontium separations and the X-ray fluorescence analyses which were performed at Oxford. David 
Elliot considerably improved our write-up of the regional synthesis, and J. Gunner and N.J. Snelling provided useful references and constructive comments. This paper is published with permission of the Director, Institute of Geological Sciences.

\section{REFERENCES}

Allsopp, H.L. and Kolbe, P., 1965. Isotopic age determinations on the Cape Granite and intruded Malmesbury sediments, Cape Peninsula, South Africa: Geochim. Cosmochim. Acta, v. 29, p. 1115-1130.

Baker, H.A., 1924. Final report on geological investigations in the Falkland Islands, 1920-1922: Stanley (Government Printer).

Beckinsale, R.D., 1974. Rb-Sr and K-Ar age determinations and oxygen isotope data for the Glen Cannel granophyre, Isle of Mull, Argyllshire, Scotland: Earth Planet. Sci. Lett., v. 22 , p. $267-274$.

Beckinsale, R.D. and Gale, N.H., 1969. A reappraisal of the decay constants and branching ratio of ${ }^{40} \mathrm{~K}$ : Earth Planet. Sci. Lett., v. 6, p. 289-294.

Beckinsale, R.D. and Obradovich, J.D., 1973. Potassiumargon ages for minerals from the Ross of Mull, Argyllshire, Scotland: Scot. J. Geol., v. 9, p. 147-156.

Bishop, D.W. and van Eeden, O.R., 1971. Explanatory text for tectonic map of Africa: Areas co-ordinated by the Southern Group: Tectonics of Africa: Paris (UNESCO), p. 561-585.

Craddock, C., 1972. Geological map of Antarctica 1:5,000,000. New York (American Geographical Society).

Dalrymple, G.B. and Lanphere, M.A., 1969. Potassiumargon dating: San Francisco (W.H. Freeman and Company).

Elliot, D.H., 1975. Tectonics of Antarctica: A review: Am. J. Sci., v. $275-A$, p. $45-106$.

Elliot, D.H. and Watts, D.R., 1974. The nature and origin of volcaniclastic material in some Karroo and Beacon rocks: Geol. Soc. S. Africa Trans., v. 77, p. 109-112.

Faure, G., Hill, R.L., Eastin, R., and Montigny, R.J.E., 1968a. Age determination of rocks and minerals from the Transantarctic Mountains: Antarctic J. U.S., Sept-Oct, p. 173-175.

Faure, G., Murtaugh, J.G., and Montigny, R.J.E., 1968b. The geology and geochronology of the basement complex of the central Transantarctic Mountains: Canadian J. Earth Sci., v. 5, p. 555-560.

Fuller, A.O., 1971. The occurrence of laumontite in strata of Karroo System, South Africa. In Haughton, S.H. (Ed.), Gondwana Symp., Proc. 2nd, CSIR Pretoria, p. 455-456.

Greenway, M.E., 1972. The geology of the Falkland Islands: British Antarctic Surv. Sci. Rept., no. 76, p. 1-42.

Grindley, G.W. and McDougall, I., 1969. Age and correlation of the Nimrod Group and other Precambrian rock units in the central Transantarctic Mountains, Antarctica: New Zealand J. Geol. Geophys., v. 12, p. 391-411.

Gunner, J. and Faure, G., 1972. Rb-Sr Geochonology of the Nimrod Group, Central Transantarctic Mountains. In Adie, R.J. (Ed.), Antarctic geology and geophysics: Oslo (Universitetsforlaget), p. 305-311.

Halpern, M., 1968. Ages of Antarctic and Argentine rocks bearing on continental drift: Earth Planet. Sci. Lett., v. 5, p. 159-167.

1971. Evidence for Gondwanaland from a Review of West Antarctic Radiometric Ages. In Research in the Antarctic: Am. Assoc. Advancement Sci., p. 717-730. 1972. Geochronologic evolution of Southern South America. In Internatl. Symp. on the Carboniferous and Permian Systems in South America, Sao Paulo, Brasil Proc. Academia Brasileira de Ciencias, p. 77-88.

Halpern, M., Linares, E., and Latorre, C.O., 1971. Edad rubidioestroncio de rocas volcanicas e hipabisales, del area norte de la Patagonia, Republica Argentina: Rev. Assoc. Geol. Argentina, v. 26, p. 169-174.

Halpern, M., Urquhart, M.U., and Linares, E., 1972. Radiometric ages of crystalline rocks from southern South America as related to Gondwana and Andean geologic provinces: International Upper Mantle Project: Conf. solid earth problems, v. II, p. 345-356.

Haughton, S.H., 1969. Geological History of Southern Africa: Cape Town (Geological Society of South Africa).

Krylov, A. Ya., 1972. Antarctic Geochronology. In Adie, R.J. (Ed.), Antarctic geology and geophysics. Oslo (Universitetsforlaget), p. 491-494.

Martini, J.E.J., 1974. On the presence of ash beds and volcanic fragments in the greywackes of the Karroo System in the southern Cape Province (South Africa). Geol. Soc. S. Africa Trans., v. 77, p. 113-116.

Moorbath, S., 1975. Geological interpretation of whole-rock isochron dates from high grade gneiss terrains: Nature, London, v. 255 , p. 391 .

Pankhurst, R.J. and O'Nions, R.K., 1973. Determination of $\mathrm{Rb} / \mathrm{Sr}$ and ${ }^{87} \mathrm{Sr} /{ }^{86} \mathrm{Sr}$ ratios of some standard rocks and evaluation of X-ray fluorescence spectrometry in $\mathrm{Rb}-\mathrm{Sr}$ geochemistry: Chem. Geol., v. 12, p. 127-136.

Pasteels, P. and Michot, J., 1970. Uranium-lead radioactive dating and lead isotope study on sphene and $\mathrm{K}$-feldspar in the Sor-Rondane Mountains, Dronning Maud Land, Antarctica: Eclog. Geol. Helv., v. 53, p. 239-254.

Stipanicic, P.N., Toubes, R.O., Spikermann, J.P., and Halpern, M., 1971. Sobre la composición y edad de algunas plutonitas del nordeste de la provincia de Santa Cruz, Patagonia, (rep. Argentina): Rev. Assoc. Geol. Argentina, v. 26, p. 459-467.

Stratten, T., 1971. Sub-Karroo geology of the Karroo Basin in South Africa. In Haughton, S.H. (Ed.), Gondwana Symp., Proc. 2nd: CISR Pretoria, p. 209-211.

Williamson, J.H., 1968. Least-squares fitting of a straight line: Canadian J. Phys., v. 46, p. 1845-1847. 